\title{
KINERJA MEMBRAN KOMPOSIT KITOSAN-KARAGENAN PADA SISTEM MICROBIAL FUEL CELL DALAM MENGHASILKAN BIOLISTRIK DARI LIMBAH PEMINDANGAN IKAN
}

\author{
Bustami Ibrahim $^{\star 1}$, Uju$^{2}$, Agus Muhamad Soleh ${ }^{1}$ \\ ${ }^{1}$ Departemen Teknologi Hasil Perairan’ Fakultas Perikanan dan Ilmu Kelautan Institut Pertanian Bogor, Kampus \\ IPB Dramaga, Jalan Agatis, Bogor 16680 Jawa Barat Telp. (0251) 8622909-8622906, Faks· (0251) 8622907 \\ ${ }^{2}$ Surfactant And Bioenergy Research Center, Jalan· Raya Pajajaran No· 1, Baranangsiang, Bogor Tengah, RT.02/RW.05, \\ Tegallega, Kecamatan Bogor Tengah, Kota Bogor, Jawa Barat 16143 Telp. (0251) 8330970 \\ Korespondensi: bustamibr@yahoo·com \\ Diterima: 20 Desember 2019/Disetujui: 13 April 2020
}

Cara sitasi: Ibrahim B, Uju, Soleh AM. 2020. Kinerja membran komposit kitosan-karagenan pada sistem microbial fuel cell dalam menghasilkan biolistrik dari limbah pemindangan ikan. Jurnal Pengolahan Hasil Perikanan Indonesia. 23(1): 137-146.

\begin{abstract}
Abstrak
Microbial fuel cell (MFC) merupakan suatu teknologi yang memanfaatkan mikroba untuk mendegradasi bahan organik dan anorganik menjadi energi listrik, dapat dilakukan menggunakan sistem satu bejana atau dua bejana. Sistem MFC dua bejana menggunakan membran penukar proton yang berfungsi untuk mengalirkan proton yang dihasilkan dari ruang anoda ke ruang katoda, salah satu alternatif membran yang digunakan yaitu komposit kitosan-karagenan. Penelitian ini bertujuan untuk menentukan perbandingan komposit kitosan-karagenan sebagai membran penukar proton pada MFC, menentukan kinerja MFC dalam menghasilkan elektrisitas, serta menentukan kinerja penurunan beban polutan limbah cair pada MFC. Nilai elektrisitas MFC diukur menggunakan multimeter dengan parameter yang diuji adalah tegangan listrik, serta arus listrik. Parameter uji yang digunakan untuk mengukur penurunan beban polutan limbah cair adalah chemical oxygen demand (COD), biologycal oxygen demand (BOD) dan total amonia nitrogen (TAN). Membran komposit kitosan-karagenan dibuat dengan perlakuan perbedaan komposisi kitosan dan karagenan $1: 1 ; 1,5: 1 ; 3: 1(\mathrm{v} / \mathrm{v})$. Perbedaan rasio kitosan dan karagenan pada membran komposit kitosan-karagenan memberikan pengaruh terhadap sifat mekanik membran, nilai elektrisitas MFC, serta beban polutan cair pada MFC. Membran komposit kitosan-karagenan dengan perbandingan 1:1 menghasilkan nilai konduktivitas proton tertinggi

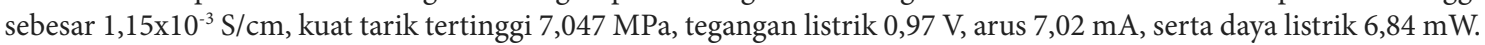
Nilai COD, BOD, serta TAN limbah cair pemindangan ikan mengalami penurunan sebesar $90 \%$, 76\% dan $32 \%$.
\end{abstract}

Kata kunci: BOD, COD, microbial fuel cell, nilai elektrisitas

\section{Performance of Chitosan-Carrageenan Composite Membrane on Microbial Fuel Cell System in Producing Bioelectricity from Boiled Fish Wastewater}

\begin{abstract}
Microbial fuel cell (MFC) is a technology that utilizes microbes to degrade organic and inorganic materials into electrical energy using one or two chambers. The two- chamber MFC system uses a proton exchange membrane to flow the protons produced at the anode to the cathode chamber. Chitosan-carrageenan composite membrane can be used as an alternative to the proton exchange membrane in the MFC of two chamber. This study was aimed to analyze the characteristics of chitosan-carrageenan composite membrane as a proton exchange membrane in MFC, determine the performance of MFC in generating the electricity, and determine the performance of the load reduction of wastewater pollutants in the MFC. The voltage and current of MFC was measured using a multimeter While the reduction of boiled fish wastewater pollutant load was determined based on the Chemical Oxygen Demand (COD), Biologycal Oxygen Demand (BOD), and Total Ammonia Nitrogen (TAN). Chitosan - carrageenan composite membrane was made using three different ratio of chitosan and carrageenan $(1: 1,1.5: 1,3: 1)$. Chitosan and carrageenan ratio on the composite membrane carrageenan influenced the mechanical properties of membranes and the value of MFC's electricity as well the load reduction of wastewater pollutans in the MFC. The chitosan-carrageenan composite membrane with a ratio of 1: 1 produced the highest proton conductivity value of $1.15 \times 10^{-3} \mathrm{~S} / \mathrm{cm}$, the highest tensile strength of $7.047 \mathrm{MPa}$, the highest electric voltage of $0.97 \mathrm{~V}$, the highest current of $7.02 \mathrm{~mA}$, and the highest electric power of $6.84 \mathrm{~mW}$. The value of COD, BOD, and TAN boiled fish wastewater decreased by $90 \%, 76 \%$, and $32 \%$, respectively.
\end{abstract}

Keywords: BOD, COD, microbial fuel cell, electrical value 


\section{PENDAHULUAN}

Peningkatan konsumsi energi listrik dapat menyebabkan krisis energi yang diakibatkan oleh kelangkaan bahan bakar pembangkit listrik. Krisis energi listrik memicu pengembangan sumber energi alternatif untuk mensubstitusi penggunaan minyak bumi, batu bara, serta gas alam sebagai sumber energi listrik bagi masyarakat. Alternatif yang dapat digunakan untuk menghasilkan energi listrik adalah teknologi microbial fuel cell (MFC). Microbial fuel cell merupakan teknologi yang memanfaatkan mikroba untuk mendegradasi bahan organik maupun anorganik menjadi energi listrik (Lee et al. 2010).

Limbah cair industri perikanan mengandung banyak bahan organik yang dihasilkan dari proses pengolahan ikan (Uju et al. 2018). Kandungan bahan organik pada limbah cair perikanan dapat menimbulkan masalah lingkungan karena menimbulkan polusi berat pada perairan (Scott dan Hui 2004). Bahan organik yang terkandung pada limbah cair perikanan dapat dimanfaatkan sebagai sumber biomassa pada microbial fuel cell (Ibrahim et al. 2014).

Sistem microbial fuel cell dapat didesain menjadi satu bejana dan dua bejana. Sistem MFC dengan satu bejana pada limbah hasil pemindangan dapat menghasilkan energi listrik dan menurunkan beban polutan misalnya BOD dan COD (Ibrahim et al. (2017a; 2017b dan 2019). Microbial fuel cell dua bejana menggunakan membran penukar proton untuk mengalirkan proton yang dihasilkan dari ruang anoda menuju ruang katoda (Flimban et al. 2019). Nafion merupakan membran penukar proton yang terbuat dari bahan polimer sintetik tetrafluoroetilen tersulfonasi (Duan et al. 2012). Nafion memiliki harga yang sangat mahal yaitu sekitar USD 33.00 (Fuel Cell Store 2019). Alternatif yang dapat dilakukan adalah membuat membran menggunakan polimer alami salah satunya kitosan dan karagenan.

Kitosan dapat digunakan sebagai membran penukar proton pada fuel cell dengan beberapa campuran polimer dan bahan anorganik karena mempunyai konduktivitas ionik yang tinggi dan bersifat polikationik
(Shaari dan Kamarudin 2015). Ibrahim et al. (2017a) melaporkan bahwa membran separator kitosan/PVA yang digunakan pada sistem MFC dapat menghasilkan tegangan listrik sebesar 0,615 V. Eldin et al. (2019) melaporkan bahwa karagenan merupakan polisakarida yang bersifat polianionik karena mempunyai gugus sulfat pada strukturnya. Menurut Cabello et al. (2014), kandungan gugus sulfat pada karagenan akan meningkatkan konduktivitas proton pada membran penukar proton. Gugus sulfat pada karagenan akan menarik dan mengalirkan proton yang dihasilkan pada sistem microbial fuel cell dari ruang anoda menuju ruang katoda. Penggunaan membran komposit kitosan-karagenan sebagai alternatif dari membran penukar proton diharapkan dapat meningkatkan kinerja MFC. Penelitian ini bertujuan untuk menentukan perbandingan komposit kitosankaragenan sebagai membran penukar proton pada MFC, menentukan kinerja MFC dalam menghasilkan elektrisitas, serta menentukan kinerja penurunan beban polutan limbah cair pada MFC.

\section{BAHAN DAN METODE Bahan dan Alat}

Bahan yang digunakan dalam penelitian ini adalah substrat limbah cair perikanan (limbah pengolahan pindang CV. Cindy Group Parung, Bogor), kitosan 80 mesh (PT Biotect), kappa karagenan (Plaza Kimia), asam asetat, lumpur aktif, akuades, $\mathrm{KMnO} 4$ (Merck), buffer fosfat (Merck), $\mathrm{KOH}$ (Merck), $\mathrm{H}_{2} \mathrm{SO}_{4}$ (Merck), PVA, larutan alkalin sitrat (Merck), natrium hipoklorit (Merck), larutan fenol (Merck), natrium nitroprusid (Merck), dan $\mathrm{KBr}$ (Merck). Alat-alat yang digunakan dalam penelitian ini adalah jerigen, gelas ukur $1 \mathrm{~L}$, desain MFC dua bejana dengan dimensi $8 \times 15 \times 8 \mathrm{~cm}$, kabel, batang grafit, elektroda tembaga, selang, sudip, blender tangan (Tokebi), kaca, pipet volumetrik (Pyrex), multimeter (UK 830LN), erlemeyer (Pyrex), tabung reaksi, alat titrasi (Pyrex), botol khusus BOD, cawan petri (Pyrex), gelas piala (Pyrex), toples plastik, kabel, buret (Pyrex), DO meter (Lutron), oven, spektrofotometer UV-VIS (Optima), pH meter (DKK-TOA), 
tensile strength tester tipe PA-104-30 (Torsee), FTIR spektrometer merk (Perkin Elmert) dan LCR-meter 3532-50 (HIOKI).

\section{Metode Penelitian}

Penelitian ini terdiri dari lima tahap, yaitu pembuatan dan karakterisasi membran komposit kitosan-karagenan, pembuatan desain MFC dua bejana, karakterisasi awal limbah air rebusan ikan pindang, pengukuran elektrisitas dari MFC dua bejana, serta pengukuran penurunan beban polutan limbah cair dengan analisis Chemical Oxygen Demand (COD), Biologycal Oxygen Demand (BOD), dan Total Amonia Nitrogen (TAN).

Pembuatan membran komposit kitosankaragenan mengacu pada penelitian Park et al. (2001) dengan modifikasi. Tahap awal pembuatan membran komposit kitosankaragenan adalah membuat larutan kitosan $2 \%(\mathrm{~b} / \mathrm{v})$ dengan melarutkan kitosan ke dalam asam asetat, serta membuat larutan karagenan $1 \%(\mathrm{~b} / \mathrm{v})$ dengan melarutkan karagenan ke dalam akuades dengan suhu $70^{\circ} \mathrm{C}$. Tahap selanjutnya larutan kitosan dicampurkan bersama larutan karagenan dengan perbandingan kitosan:karagenan 3:1, 1,5:1, dan 1:1 (v/v). Larutan yang telah dicampurkan kemudian ditambahkan dengan PVA 5\% (v/v). Larutan diaduk dengan menggunakan blender tangan hingga homogen. Larutan yang telah homogen selanjutnya dituangkan ke dalam cetakan cawan petri dan dikeringkan pada suhu $70^{\circ} \mathrm{C}$ selama 12 jam pada oven hingga diperoleh film kitosan karagenan kering. Membran kemudian dilepaskan dari cetakan dengan perendaman menggunakan $\mathrm{KOH} 1 \%$ selama 10 menit. Membran kemudian dibilas dengan akuades hingga $\mathrm{pH}$ netral. Membran yang terbentuk kemudian dikarakterisasi melalui pengujian sifat mekanik (ASTM 2002), analisis konduktivitas proton (Handayani et al. 2010), dan analisis gugus fungsi (Skoog et al. 1996).

Sifat mekanik membran diuji menggunakan alat Tensile Strength Tester merk Torsee tipe PA-104-30. Ukuran membran yang digunakan sebesar $1,5 \mathrm{~cm}$ untuk lebar dan panjangnya disesuaikan dengan alat ukur. Membran kemudian dijepit dan ditarik sampai putus oleh alat Tensile Strength Tester.
Hasil pengujian kemudian dicatat tegangan maksimum dan regangannya. Nilai kuat tarik membran dihitung dengan menggunakan rumus berikut.

kuat tarik $=\frac{16}{\mathrm{~N}} \times \frac{\text { hasil uji }}{\mathrm{t} \times \mathrm{l}} \times 0,1$

Keterangan:

$\mathrm{N}=$ jumlah pengukuran

$\mathrm{t}=$ tebal membran $(\mathrm{cm})$

$1=$ lebar membran $(\mathrm{cm})$

Konduktivitas proton membran komposit kitosan-karagenan diukur menggunakan spektrometer impedans LCR-meter HIOKI 3532-50. Ukuran membran yang digunakan ukuran 2,5x2,5 cm. Membran kemudian dijepit di antara dua elektroda karbon dan diukur nilai konduktansinya. Membran diukur juga ketebalannya menggunakan mikrometer. Nilai konduktivitas proton (S/ $\mathrm{cm}$ ) dihitung menggunakan persamaan :

$\sigma=G \frac{L}{A}$

Keterangan:

$\sigma=$ konduktivitas proton $(\mathrm{S} / \mathrm{cm})$

$\mathrm{G}=$ nilai konduktivitas $(\mathrm{S})$

$\mathrm{L}=$ jarak antara kedua elektrode $(\mathrm{cm})$

$\mathrm{A}=$ luas permukaan $\left(\mathrm{cm}^{2}\right)$

Gugus fungsi membran komposit kitosan-karagenan dianalisis menggunakan alat Fourier Transform Infrared (FTIR) Spectrometer Perkin Elmert Spectrume One. Langkah yang pertama sampel membran dengan ukuran $2 \times 2 \mathrm{~cm}$ ditempelkan pada wadah yang terdapat pada alat DRS. Serbuk $\mathrm{KBr}$ yang digunakan kemudian digerus menggunakan mortar serta dimasukan kedalam lubang silinder. Sinar inframerah yang ditembakkan pada membran akan direkam sebagai gelombang dengan spektrum antara $500-4000 \mathrm{~cm}^{-1}$.

Pembuatan desain MFC dilakukan dengan menyiapkan dua bejana yang terbuat dari kaca dengan ukuran $8 \times 15 \times 8 \mathrm{~cm}$. Dua bejana tersebut digunakan sebagai ruang anoda dan katoda. Membran komposit kitosan-karagenan diletakkan diantara ruang katoda dan anoda dengan diameter membran sebesar $5 \mathrm{~cm}$. Batang grafit digunakan sebagai 
elektroda katoda dan tembaga digunakan sebagai elektroda anoda. Skema desain MFC dua bejana dapat dilihat pada Figure 1 .

Lumpur aktif yang akan digunakan harus aklimatisasi terlebih dahulu dengan ditambahan ke dalam limbah cair pemindangan ikan dengan perbandingan 1:3 (v/v). Proses aklimatisasi lumpur aktif dilakukan selama 48 jam. Lumpur aktif yang telah diaklimatisasi kemudian dimasukan kedalam ruang anoda serta ditambahkan limbah cair dengan perbandingan 1:10 (v/v). Ruang katoda diisi oleh larutan $\mathrm{KMnO} 4$ 0,01 $M$ dan buffer fosfat dengan perbandingan 9:1 (v/v) yang berfungsi sebagai larutan elektrolit. Sistem MFC kemudian diukur elektrisitasnya setiap jam selama 120 jam.

Parameter uji yang digunakan untuk mengukur penurunan beban polutan limbah cair adalah nilai $\mathrm{pH}$, Chemical Oxygen Demand (COD), Biologycal Oxygen Demand (BOD), dan Total Amonia Nitrogen (TAN). Pengujian COD dilakukan dengan cara sampel diencerkan menggunakan akuades sebanyak 25 kali pengenceran. Tabung refluks yang akan digunakan harus ditutup dan dicuci terlebih dahulu menggunakan $\mathrm{H}_{2} \mathrm{SO}_{4}$ 20\%. Tahap selanjutnya sampel dipipet sebanyak $2,5 \mathrm{~mL}$ lalu dimasukkan ke dalam tabung refluks. Sampel kemudian ditambahkan dengan larutan pencerna sebanyak $1,5 \mathrm{~mL}$ dan pereaksi asam sulfat sebanyak 3,5 mL. Larutan standar dibuat dengan menambahkan larutan pencerna sebanyak $1,5 \mathrm{~mL}$ dan pereaksi asam sulfat sebanyak 3,5 mL. Larutan standar yang telah dibuat kemudian dimasukkan kedalam tabung refluks. Tabung refluks ditutup dan dihomogenkan menggunakan vortex. Tabung refluks diletakkan pada COD reaktor yang telah dipanaskan pada suhu $150^{\circ} \mathrm{C}$ selama 2 jam. Sampel kemudian didinginkan dan dibaca serapan larutan menggunakan spektrofotometer UV-VIS dengan panjang gelombang $600 \mathrm{~nm}$.

Pengujian BOD dilakukan dengan cara sampel limbah dimasukkan ke dalam erlenmeyer lalu diencerkan menggunakan akuades dengan faktor pengenceran 10 sampai $200 \mathrm{~mL}$. Sampel kemudian diaerasi selama 30 menit. Sampel dipisahkan pada dua botol BOD yang digunakan untuk inkubasi dan mengukur DO pada larutan sampel. Botol sampel yang digunakan untuk inkubasi merupakan botol khusus BOD, serta pada saat proses inkubasi tidak boleh ada gelembung udara pada botol BOD tersebut. Proses inkubasi sampel dilakukan selama lima hari di tempat gelap pada suhu $20^{\circ} \mathrm{C}$. Nilai DO diukur untuk sampel yang telah diinkubasi, dan kontrol.

Penentuan nilai TAN dilakukan dengan cara sampel dipipet sebanyak 25 $\mathrm{mL}$ dan dimasukkan ke dalam erlenmeyer 50 $\mathrm{mL}$. Sampel kemudian ditambahkan dengan larutan fenol $1 \mathrm{~mL}$, natrium nitroprusfid sebanyak $1 \mathrm{~mL}$ serta larutan pengoksidasi sebanyak 2,5 mL lalu dihomogenkan. Larutan pengoksidasi dibuat dengan mencampurkan larutan alkalin sitrat sebanyak $100 \mathrm{~mL}$ dengan larutan natrium hipoklorit sebanyak $25 \mathrm{~mL}$. Sampel pada erlenmeyer kemudian ditutup menggunakan plastik atau parafin. Sampel kemudian dibiarkan selama 1 jam sampai terbentuknya warna. Sampel kemudian dimasukan kedalam kuvet pada alat spektrofotometer dengan panjang gelombang $640 \mathrm{~nm}$.

\section{HASIL DAN PEMBAHASAN Karakteristik Sifat Mekanik Membran Komposit Kitosan-Karagenan}

Karakterisasi sifat mekanik digunakan untuk mengetahui kekuatan membran terhadap gaya yang dapat merusak membran

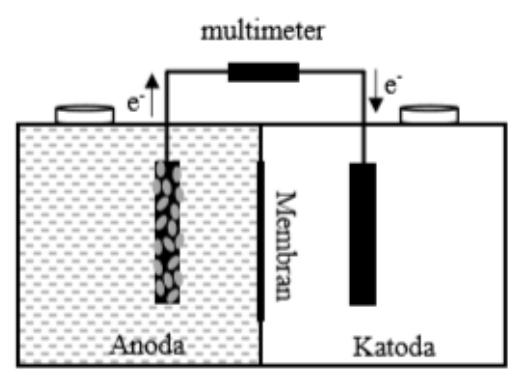

Figure 1 Microbial Fuel Cell two chambers design 
(Ayuni et al. 2018). Kuat tarik erat kaitannya dengan sifat mekanik membran yang merupakan parameter penting karena menjadi pertimbangan dalam pemilihan membran untuk digunakan pada MFC. Hasil uji kuat tarik membran komposit kitosan-karagenan dapat dilihat pada Figure 2.

Kuat tarik dari dari sebuah membran dapat dipengaruhi oleh interaksi antar molekul bahan penyusun membran (Rusli et al. 2017). Perlakuan dengan perbandingan komposisi kitosan dan karagenan 1:1 menghasilkan nilai kuat tarik tertinggi. Kombinasi yang seimbang dari ikatan ionik antara karagenan dan kitosan, serta ikatan hidrogen antar molekul karagenan akan meningkatkan kuat tarik dari membran komposit kitosan-karagenan (Yu et al. 2018). Nilai kuat tarik yang rendah dari sebuah membran akan menyebabkan membran mudah mengalami kerusakan. Kerusakan tersebut dapat disebabkan oleh beberapa faktor seperti perubahan suhu, kelembaban, dan tekanan oleh air (Kusoglu et al. 2007).

\section{Gugus Fungsi Membran Komposit Kitosan-Karagenan}

Hasil spektrum membran komposit kitosan-karagenan menunjukkan bahwa terdapat bilangan gelombang 1668-1644 $\mathrm{cm}^{-1}$ yang menunjukkan gugus fungsi dari amida I. Bilangan gelombang 1446-1428 $\mathrm{cm}^{-1}$ menunjukkan gugus fungsional $-\mathrm{OSO}_{3}$. Bilangan gelombang 3607-3583 $\mathrm{cm}^{-1}$ menunjukkan ikatan hidroksil. Bilangan gelombang $967 \mathrm{~cm}^{-1}$ dan $937 \mathrm{~cm}^{-1}$ yang terdapat perlakuan dengan perbandingan 1:1 dan 1,5:1 merupakan gugus 3,6-anhidrogalaktosa. Bilangan gelombang $842 \mathrm{~cm}^{-1}$ yang terdapat pada perlakuan perbandingan 1:1 merupakan gugus fungsi dari galaktosa-4sulfat. Bilangan gelombang $1237 \mathrm{~cm}^{-1}$ yang terdapat pada perlakuan 1,5:1 merupakan gugus fungsi dari ester sulfat pada karagenan. Bilangan gelombang $1035 \mathrm{~cm}^{-1}, 1147 \mathrm{~cm}^{-1}$ yang terdapat pada perlakuan 1,5:1 dan 3:1 merupakan ikatan C-O-C. Hasil spektrum FTIR membran komposit kitosan-karagenan dapat dilihat pada Figure 3.

\section{Konduktivitas Proton Membran Komposit Kitosan-Karagenan}

Konduktivitas proton merupakan migrasi proton yang terjadi pada membran penukar proton melalui ikatan hidrogen pada (Wafiroh et al. 2016). Konduktivitas proton membran merupakan fungsi utama dari membran penukar proton yang digunakan pada sistem MFC. Nilai konduktivitas proton membran komposit kitosan-karagenan dapat dilihat pada Figure 4.

Nilai konduktivitas proton tertinggi terdapat pada perlakuan dengan perbandingan 1:1. Peningkatan konsentrasi kitosan pada membran komposit kitosan-karagenan akan menurunkan ukuran pori pada membran (Siswanto 2013). Penurunan ukuran pori pada membran akan menurunkan jumlah proton yang melewati membran. Peningkatan konsentrasi karagenan berbanding lurus dengan peningkatan konduktivitas proton membran. Hal ini disebabkan karena kandungan gugus sulfat pada karagenan yang bersifat polianionik akan menarik proton untuk melewati membran (Cabello et al. 2014).

\section{Elektrisitas MFC}

Nilai tegangan, kuat arus, dan daya listrik yang dihasilkan pada sistem MFC

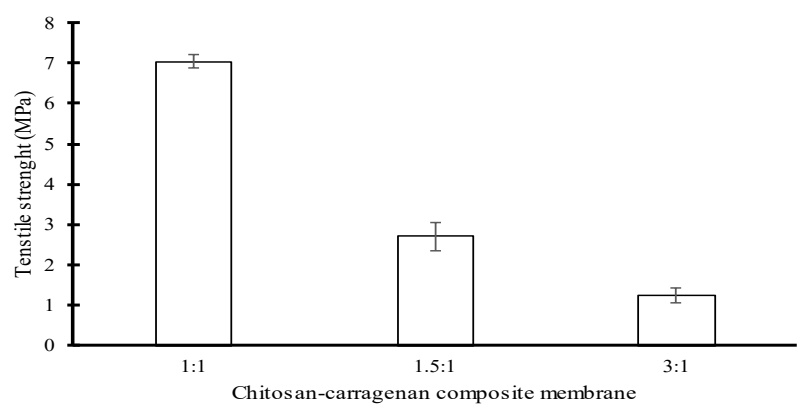

Figure 2 Ratio of tensile strength value of chitosan-carrageenan composite membrane 
diukur menggunakan multimeter digital dalam satuan volt, miliampere, dan miliwatt. Nilai elektrisitas pada sistem MFC diukur selama 120 jam. Hasil nilai elektrisitas pada MFC dapat dilihat pada Figure 5.

Nilai tegangan listrik, arus listrik, dan daya listrik yang dihasilkan dari sistem MFC mengalami fluktuasi selama pengamatan. Hasil uji statistik $(\mathrm{p}<0.05)$ menunjukkan bahwa perbedaan perbandingan komposisi membran komposit kitosan-karagenan memberikan pengaruh nyata terhadap nilai tegangan listrik, dan daya listrik yang dihasilkan pada sistem MFC dua bejana, sedangkan arus listrik yang dihasilkan dari membran komposit kitosankaragenan dengan perlakuan 1:1 dan 1.5:1 tidak berbeda secara siginifikan $(p>0.05)$. Nilai elektrisitas tertinggi terdapat pada MFC dengan perlakuan komposisi kitosankaragenan 1:1 yang menghasilkan tegangan, arus, dan daya listrik masing-masing yaitur 0,97 V, 7,02 mA, dan 6,84 mW.

Nilai elektrisitas yang dihasilkan berbanding lurus dengan besarnya konduktivitas proton membran. Membran penukar proton mempunyai peranan penting pada sistem MFC dalam menghasilkan energi listrik. Proton yang dihasilkan pada ruang anoda akan dialirkan menuju ruang katoda melalui membran penukar proton.
Nilai konduktivitas proton yang tinggi akan meningkatkan jumlah proton yang dialirkan dari ruang anoda menuju ruang anoda, sehingga akan meningkatkan nilai elektrisitas yang dihasilkan pada MFC (Kim et al. 2007).

Nilai elektrisitas yang fluktuatif dapat disebabkan oleh aktivitas mikroba pendegradasi substratyangterdapatpadaMFC. Peningkatan nilai elektrisitas yang terukur dapat disebabkan oleh peningkatan aktivitas mikroba saat melakukan pemecahan substrat menjadi senyawa yang lebih sederhana, sedangkan penurunan nilai elektrisitas dapat disebabkan oleh kondisi mikroba yang mulai memasuki fase kematian. Kematian sel mikroba tersebut dapat disebabkan oleh penurunan jumlah nutrien yang terdapat pada substrat sehingga kecepatan metabolisme mikroba akan semakin menurun. Penurunan kecepatan metabolisme bakteri akan berpengaruh terhadap penurunan energi listrik yang dihasilkan (Lee et al. 2010).

\section{Kinerja Penurunan Beban Polutan Limbah Cair dalam Sistem MFC}

Limbah cair perikanan mengandung Chemical Oxygen Demand (COD), Biological Oxygen Demand (BOD) serta senyawa nitrogen yang sangat tinggi (Chowdhury et al. 2010). Kandungan BOD, COD, TAN serta
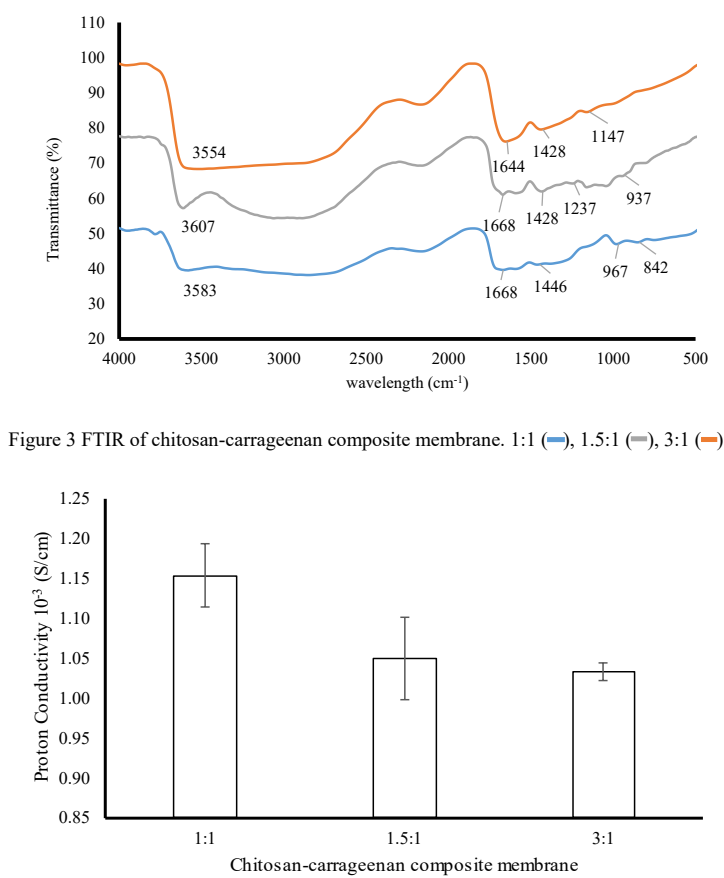

Figure 4 Proton conductivity of chitosan-carrageenan composite membrane 

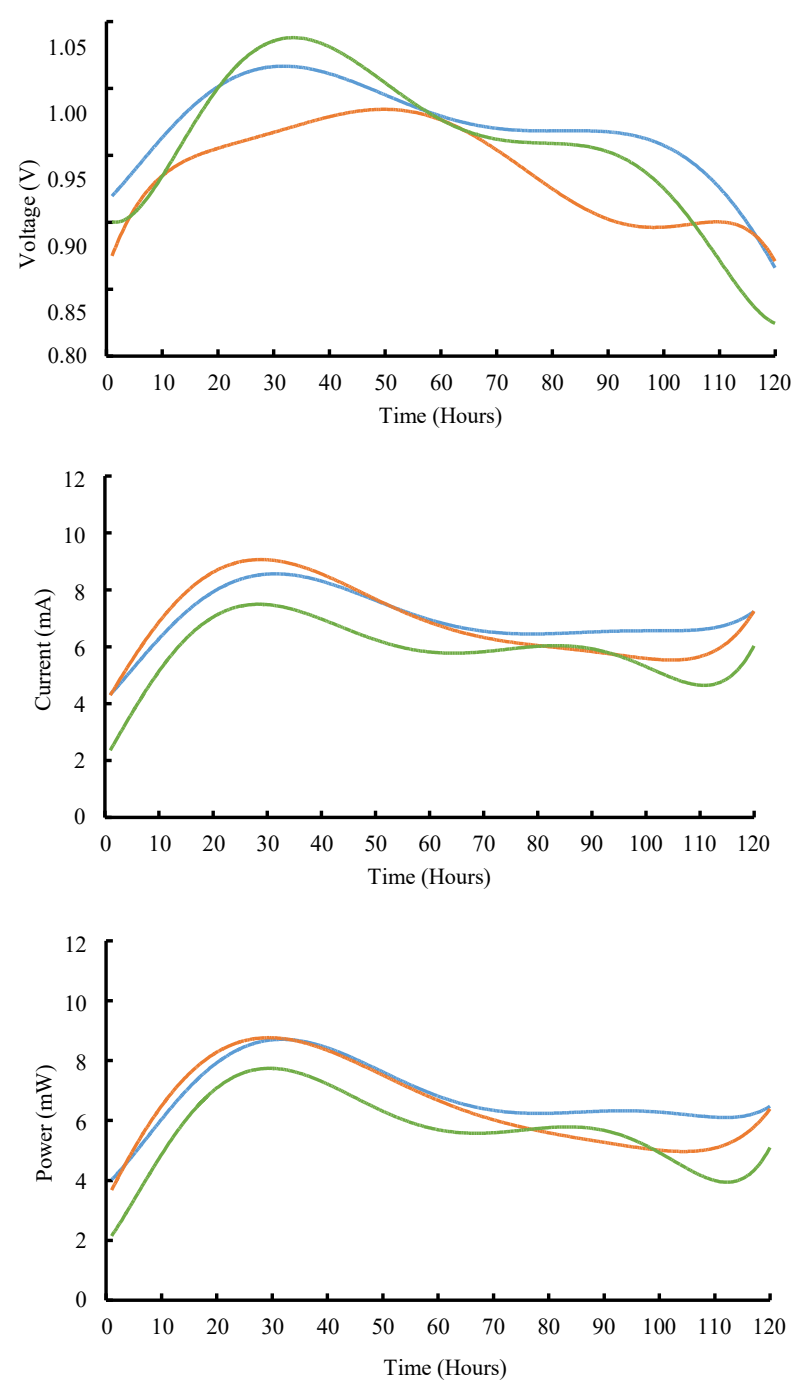

Figure 5 Electricity value of MFC : $1: 1(-), 1.5: 1(-), 3: 1(-)$

nilai $\mathrm{pH}$ menjadi parameter bagi baku mutu limbah cair perikanan. Karakteristik limbah cair ikan pindang dapat dilihat pada Table 1.

\section{Nilai COD}

Hasil uji statistik $(\mathrm{p}<0.05)$ menunjukkan bahwa perbedaan perbandingan komposisi membran komposit kitosan karagenan memberikan pengaruh nyata terhadap penurunan nilai COD yang dihasilkan pada sistem MFC dua bejana. Penurunan kadar COD terbesar terdapat pada perlakuan membran dengan komposisi membran 1:1 yaitu $90 \%$.

Perbedaan penurunan nilai COD tersebut dapat disebabkan oleh penurunan kandungan senyawa anorganik pada limbah cair pemindangan ikan seperti $\mathrm{NaCl}$ Sodium $\left(\mathrm{Na}^{+}\right)$yang terdapat pada limbah cair perikanan akan dialirkan oleh membran penukar proton dari ruang anoda menuju ruang katoda. Jumlah sodium yang dialirkan dipengaruhi oleh besarnya konduktivitas proton pada membran penukar proton (Kim et al. 2007).

\section{Nilai BOD}

Hasil uji statistik $(\mathrm{p}<0,05)$ menunjukkan bahwa perbedaan perbandingan komposisi membran komposit kitosan karagenan tidak berpengaruh nyata pada perlakuan 1.5:1 dan $3: 1$, serta berpengaruh nyata pada perlakuan 1:1 terhadap penurunan nilai BOD yang dihasilkan pada sistem MFC dua bejana. Penurunan kadar BOD terbesar terdapat pada perlakuan membran dengan komposisi membran 1:1 yaitu $r 76 \%$. 
Table 1 Boiled fish wastewater quality changes during MFC process

\begin{tabular}{|c|c|c|c|c|c|}
\hline \multirow{2}{*}{ Parameters } & \multirow{2}{*}{$\begin{array}{l}\text { Boiled fish } \\
\text { wastewater }\end{array}$} & \multicolumn{3}{|c|}{ Chitosan-carrageenan composite membrane } & \multirow{2}{*}{$\begin{array}{l}\text { Quality standard of } \\
\text { fishery wastewater }\end{array}$} \\
\hline & & $1: 1$ & $1.5: 1$ & $3: 1$ & \\
\hline $\mathrm{pH}$ & $6.8 \pm 0.1$ & $8.4 \pm 0.1^{b}$ & $8.6 \pm 0.1^{\mathrm{a}}$ & $8.1 \pm 0.1^{\mathrm{c}}$ & $6-9$ \\
\hline $\mathrm{COD}(\mathrm{mg} / \mathrm{L})$ & $1798.8 \pm 12.68$ & $179.9 \pm 20^{c}$ & $339.8 \pm 20^{\mathrm{b}}$ & $919.4 \pm 40^{\mathrm{a}}$ & 150 \\
\hline $\mathrm{BOD}(\mathrm{mg} / \mathrm{L})$ & $625 \pm 3$ & $147 \pm 6^{\mathrm{b}}$ & $291 \pm 3.055^{\mathrm{a}}$ & $293 \pm 3.055^{\mathrm{a}}$ & 75 \\
\hline TAN (mg/L) & $0.156 \pm 0.007$ & $0.106 \pm 0.007^{b}$ & $0.144 \pm 0.007^{\mathrm{a}}$ & $0.133 \pm 0.007^{\mathrm{a}}$ & 5 \\
\hline
\end{tabular}

Penurunan nilai BOD pada limbah cair pemindangan ikan dapat disebabkan oleh komponen organik yang terkandung pada limbah cair mengalami proses degradasi (Ibrahim et al. 2014). Perbedaan penurunan nilai BOD tersebut dapat disebabkan oleh b koefisien massa transfer oksigen dari membran penukar proton. Koefisien massa transfer oksigen tersebut akan berpengaruh terhadap difusi oksigen dari ruang anoda menuju ruang katoda. Oksigen yang memasuki ruang anoda akan digunakan oleh bakteri aerobik untuk mendegradasi asetat (Kim et al. 2007).

\section{Nilai TAN}

Hasil uji statistik $(\mathrm{p}<0,05)$ menunjukkan bahwa perbedaan perbandingan komposisi membran komposit kitosan karagenan tidak berpengaruh nyata pada perlakuan 1,5:1, dan 3:1, serta berpengaruh nyata pada perlakuan 1:1 terhadap penurunan nilai TAN yang dihasilkan pada sistem MFC dua bejana. Penurunan kadar TAN terbesar terdapat pada perlakuan membran dengan komposisi membran 1:1 yaitu 32\%.

Penurunan nilai TAN pada limbah cair pemindangan ikan dapat disebabkan oleh bakteri nitrifier yang terdapat pada lumpur aktif. Bakteri nitrifier akan mendegradasi kandungan amonia pada limbah menjadi nitrit dan nitrat (Jamieson et al. 2003). Perbedaan penurunan nilai TAN dapat disebabkan oleh jumlah oksigen yang terdifusi kedalam ruang anoda. Bakteri nitrifikasi akan menggunakan oksigen pada proses degradasi senyawa amonia menjadi nitrit (Madigan 2009).

\section{Nilai $\mathbf{p H}$}

Nilai pH merupakan salah satu parameter pada baku mutu limbah cair perikanan. Nilai
pH pada limbah cair perikanan yang sesuai dengan PERMEN-LH No. 24 tahun 2014 yaitu sebesar 6-9. Proses degradasi senyawa organik oleh mikroorganisme menjadi produk akhir misalnya trimetilamin, dan senyawa volatile pada limbah cair pemindangan ikan akan meningkatkan nilai $\mathrm{pH}$ pada limbah akhir (Retnosari dan Shovitri 2013). Kenaikan nilai $\mathrm{pH}$ juga dapat disebabkan oleh menurunnya jumlah oksigen yang digunakan oleh bakteri saat menguraikan bahan organik (Nugrahini et al. 2008). Nilai pH yang dihasilkan masih memenuhi standar baku mutu limbah untuk industri pengolahan ikan yaitu 6-9 (KLH 2014).

\section{KESIMPULAN}

Perbedaan komposisi kitosan dan karagenan pada membran komposit kitosankaragenan memberikan pengaruh nyata terhadap sifat mekanik membran, nilai elektrisitas MFC serta beban polutan pada limbah pemindangan ikan. Perlakuan terbaik terdapat pada komposisi kitosan karagenan dengan perbandingan 1:1. Membran komposit kitosan- karagenan dengan perbandingan 1:1 menghasilkan nilai konduktivitas proton $1,15 \times 10^{-3} \mathrm{~S} / \mathrm{cm}$, kuat tarik 7,047 MPa, tegangan listrik $0,97 \mathrm{~V}$, arus 7,02 mA, serta daya listrik 6,84 mW. Nilai COD, BOD, serta TAN limbah cair pemindangan ikan mengalami penurunan sebesar 90\%, 76\% dan 32\%.

\section{DAFTAR PUSTAKA}

[ASTM] American Standard Testing and Material. 2002. ASTM C39-86 Standard Test Method for Compressive Strength of Cylindrical Concrete Specimens. Philadelphia (US): ASTM International. Ayuni NPS, Yuningrat NW, Citra NW. 2018. 
Kajian transpor kreatinin menggunakan membran kitosan-alginat tertaut silang polivinil alkohol (PVA). Jurnal Rekayasa Proses. 12(2): 114-120.

Cabello SDP, Molla S, Ochoa NA, Marchese J, Gimenez E, Compan V. 2014. New bio-polymeric membranes composed of alginate-carrageenan to be applied as polymer electrolyte membranes for DMFC. Journal of Power Sources. 265: 345-355.

Chowdhury P, Viraraghavan T, Srinivasan A. 2010. Biological treatment processes for fish processing wastewater. Bioresource Technology. 101: 439-449.

Duan Q, Wang H, Benziger J.2012. Transport of liquid water through nafion membranes. Journal of Membrane Science. 392: 88-94.

Eldin MSM, Farag HA, Tamer TM, Konsowa AH, Gouda MH. 2019. Development of novel iota carrageenan-g-polyvinyl alcohol polyelectrolyte membrane for direct methanol fuel cell application. Polymer Bulletin. 1: 1-19.

Flimban SGA, Ismail AMI, Kim T, Oh S. 2019. Overview of recent advancement in the microbial fuel cell from fundamentals to applications: design, major elements, and scalability. Energies. 12: 3390-3410.

Fuel Cell Store. 2019. Nafion TM Membran [Internet]. [diunduh 2019 Nov 22]. Tersedia pada : https://www.fuelcellstore. com.

Handayani S, Hardi J, Dewi EL. 2010. Membran elektrolit nano silika dengan polieter-eter keton tersulfonasi untuk methanol fuel cell. Jurnal Nanoteknologi Indonesia. 1(1) : 34-39.

Ibrahim B. 2005. Kaji ulang sistem pengolahan limbah cair industri hasil perikanan secara biologis dengan lumpur aktif. Buletin Teknologi Hasil Perikanan. 8(1) : 31-41.

Ibrahim B, Salamah E, Alwinsyah R. 2014. Pembangkit biolistrik dari limbah cair industri perikanan menggunakan microbial fuel cell dengan jumlah elektroda yang berbeda. Jurnal Dinamika Maritim. 4(1): 1-9.

Ibrahim B, Suptijah P, Agung BS. $2017 b$. Pengaruh jarak elektroda microbial fuel cell pada limbah cair pemindangan ikan terhadap elektrisitas dan beban pencemaran. Jurnal Pengolahan Hasil Perikanan Indonesia. 20(3): 559-567

Ibrahim B, Suptijah P, Syahreza F. 2017a. Kinerja microbial fuel cell pada pengolahan limbah cair pemindangan dengan membran separator campuran polimer kitosan/PVA. Jurnal Teknologi Industri Pertanian. 27(3): 235-241.

Ibrahim B, Uju, Mukti AC. 2019. Densitas biofilm pada elektroda berpengaruh positif terhadap produksi biolistrik microbial fuel cell limbah cair perikanan. Jurnal Pengolahan Hasil Perikanan Indonesia. 22(1): 71-79.

Jamieson TS, Stratton GW, Gordon R, Madan A. 2003. The use of aeration to enhance ammonia nitrogen removal in constructed wetlands. Canadian Biosystem Engineering. 45(1): 9-14.

Kim RJ, Cheng S, Oh SE, Logan B. 2007. Power generation using different cation, anion, and ultrafiltration membran in microbial fuel cells. Environmental Science Technology. 41 :1004-1009.

Kusoglu A, Karlsson AM, Santare MH, Cleghorn S, Johnson WB. 2007. Mechanical behavior of fuel cell membranes under humidity cycles and effect of swelling anisotropy on the fatigue stresses. Journal of Power Sources. 170: 345-358.

Lee SW, Jeon BY, Park DH. 2010. Effect of bacterial cell size on electricity generation in A single chambered in microbial fuel cell. Biochemical Engineering Journal. 111: 34-42.

MadiganMT.2009.BrockBiologyofMicroorganisms 12th Edition. San Francisco (US) : Pearson.

Nugrahini P, Habibi TMR dan Safitri AD. Penentuan parameter kinetika proses anaerobik campuran limbah cair industri menggunakan reaktor up flow anaerobic sludge blanket (UASB). Prosiding Seminar Nasional Sains dan Teknologi-II; 2008; Lampung, Indonesia. Lampung (ID): UNILA.

Park SY, Lee BI, Jung ST, Park HJ. 2001. Biopolymer composite films based on k-carrageenan and chitosan. Materials 
Research Bulletin. $36: 511-519$.

[PERMEN-LH] Peraturan Menteri Lingkungan Hidup. 2014. Peraturan Menteri Lingkungan Hidup Republik Indonesia Nomor 5 Tahun 2014 Tentang Baku Mutu Air Limbah. Jakarta (ID): Kementerian Lingkungan Hidup Republik Indonesia.

Retnosari AA dan Shovitri M. 2013. Kemampuan isolat Bacillus sp. dalam mendegradasi limbah tangki septik. Jurnal Sains dan Seni Pomits. 2(1) : 23373520.

Rusli A, Metusalach, Salengke, Tahir MM. 2017. Karakterisasi edible film karagenan dengan pemlastis gliserol. Jurnal Pengolahan Hasil Perikanan Indonesia. 20(2) : 219-229.

Scott SJ, Hui YH, 2004. Food Processing: Principles and Applications. Iowa (US) : Black Well.

Shaari N, Kamarudin SK. 2015. Chitosan and alginate types of bio membrane in fuel cell application: An overview. Journal of Power Sources. 289 : 71-80.

Siswanto. 2013. Sintesis dan karakterisasi kitosan-alginat sebagai kandidat membran pada aplikasi hemodialisa [skripsi]. Surabaya (ID) : Universitas Airlangga.

SkoogDA,HollerFJ,NiemanTA. 1996.Principle of Instrumental Analysis 4th edition. New York (US): Saunders College Publishing. Uju, Riyanto B, Ibrahim B, Ramadhan W, Tanjung IS. 2017. Proses recovery dan pengkonsentrasian protein air perebusan pindang tongkol (Euthynnus affinis) melalui ultrafiltrasi. Jurnal Teknologi industri Pertanian. 27(3): 281-290.

Yu HC, Zhang H, Ren K, Ying Z, Zhu F, Qian J, Ji J, Wu ZL, Zheng Q. 2018. Ultrathin $\mathrm{k}$ - carrageenan/chitosan hydrogel films with high toughness and antiadhesion. Applied Material and Interfaces. 10(10) : 9002-9009. 